\title{
Gambaran Pengetahuan Dan Sikap Remaja Tentang Perilaku Merokok Di SMP Free Metodist 1 Medan Jl. Beringin Raya No. 152E, Helvetia, Kec. Medan Helvetia Tahun 2021
}

\author{
Penulis: \\ Novaria Manullang ${ }^{1}$ \\ Risda Mariana Manik ${ }^{2}$ \\ Aprilita Br. Sitpu ${ }^{3}$ \\ Merlina Sinabariba ${ }^{4}$
}

Afiliasi:

STIKes Santa Elisabeth Medan ${ }^{1,2,3}$

Korespondensi: novariiia27@gmail.co

\begin{abstract}
Abstrak: Perilaku merokok adalah perilaku yang beresiko terhadap kesehatan (merokok, narkoba, minuman keras), beresiko terhadap masa depan (putus sekolah, kehamilan tidak diinginkan, konsep diri yang tidak cukup) dan beresiko terhadap lingkungan sosialnya (pengangguran, kriminalitas). Penelitian ini bertujuan untuk mengetahui Gambaran Pengetahuan Dan Sikap Remaja Tentang Perilaku Merokok Di SMP Free Metodist 1 Medan Jl. Beringin Raya No 152E Helvetia, Kec. Medan Helvetia Tahun 2021. Penelitian ini dilakukan dengan metode deskriptif, pengambilan sampel dilakukan secara metode Teknik Accidental sampling yaitu cara pengambilan sampel seketemunya, teknik ini didasarkan pada yang kebetulan ada atau yang bersedia untuk diteliti sebanyak 30 responden. Hasil penelitian ini didapat bahwa, pengetahuan responden dalam penelitian ini memiliki paling banyak berpengetahuan kurang sebanyak 12 orang $40,0 \%$, berpengetahuan cukup 11 orang $36,7 \%$ dan berpengetahuan baik 7 orang $23,3 \%$. Serta dilihat dari sikap responden ditemukan bahwa seluruh responden memiliki bersikap positif sebanyak 30 orang $100 \%$. Peneliti menyarankan agar SMP Free Metodist 1 Medan lebih meningkatkan sumber informasi mengenai rokok dengan membangun kerjasama dengan petugas kesehatan serta pihak yang bersangkutan dengan kesiswaan seperti guru BK dengan cara memaparkan apa saja mengenai rokok kepada siswa disela apel pagi dan kepada peneliti selanjutnya untuk menambah wawasan dengan menggali lebih dalam lagi apa saja faktor penyebab yang menghalangi remaja mendapatkan sumber informasi mengenai pengetahuan tentang merokok.
\end{abstract}

Kata kunci: Pengetahuan; Sikap; Perilaku Merokok.

\section{Pendahuluan}

Menurut WHO , Remaja adalah penduduk dalam rentang usia 10-19 tahun, menurut peraturan menteri kesehatan RI nomor 25 tahun 2014 , remaja adalah penduduk dalam rentang usia 10-18 tahun dan menurut badan kependudukan dan keluarga berencana (BKKBN) rentang usia remaja 10-24 tahun dan belum menikah . (Kementerian Kesehatan Republik Indonesia, 2017).

Berdasarkan sensus penduduk, jumlah kelompok usia 10-19 tahun di Indonesia sebanyak 43,5 juta atau sekitar 18\% dari jumlah penduduk. Di dunia diperkirakan kelompok remaja berjumlah 1,2 miliyar atau 18\% dari jumlah penduduk dunia. (Kementerian Kesehatan Republik Indonesia, 2017).

Merokok merupakan salah satu kebiasaan yang sangat sering kita temui dalam kehidupan sehari-hari. Dimana-mana mudah menemukan orang merokok, lelaki maupun wanita, anak kecil dan orang tua, tidak ada terkecuali. Merokok merupakan bagian hidup masyarakat. Dari segi kesehatan, tidak ada satu titik yang menyetujui atau melihat manfaat yang dikandung oleh rokok. Namun tidak mudah mengendalikan atau menurunkan terlebih menghilangkan keinginan merokok. Karena itu, gaya hidup merokok ini menjadi suatu masalah kesehatan, minimal sebagai faktor resiko yang mendukung terjadinya berbagai macam penyakit dan membawa kematian berjuta penduduk dunia. (Kesehatan, 2019)

Perilaku merokok merupakan perilaku yang berbahaya bagi kesehatan, tetapi masih banyak orang yang melakukannya, bahkan orang mulai m erokok ketika dia masih remaja. Perilaku merokok adalah perilaku yang dinilai sangat merugikan dilihat dari berbagai sudut pandang baik bagi diri sendiri maupun orang lain disekitarnya. Salah satu penyebab mengapa perokok baru terus bertambah adalah karena gencarnya iklan rokok yang beredar di masyarakat, ditambah dengan adanya image yang dibentuk oleh iklan rokok 
tersebut sehingga terlihat seakan orang yang merokok adalah orang yang sukses dan tangguh yang dapat melalui rintangan apapun. Iklan, promosi ataupun sponsor kegiatan yang dilakukan oleh para produsen rokok merupakan sarana yang sangat ampuh untuk mempengaruhi remaja dan anak-anak. Merokok mengakibatkan penurunan kesehatan yang berdampak pada penurunan kualitas anak-anak, generasi yang baru dilahirkan. Penurunan kualitas generasi penerus bangsa berakibat terjadinya pembodohan dan pemiskinan yang berkelanjutan dari generasi ke generasi sepanjang sejarah. (Sulastri \& Rindu, 2019).

Dampak perilaku rokok yang merugikan tersebut tidak serta merata membuat orang untuk menolak perilaku ini. Berdasarkan data WHO (2018) jumlah perokok di dunia terus mengalami peningkatan. Jumlah perokok di dunia diperkirakan berkisar di angka 1.1. miliar. $80 \%$ dari jumlah tersebut berasal dari negara-negara berkembang seperti Indonesia. Jumlah perokok di Indonesia adalah nomor satu di Asia Tenggara dan urutan ketiga di dunia setelah Tiongkok dan India. (Susanto, 2020).

Menurut Data WHO (World Health Organization) tahun 2017 Indonesia menempati peringkat ketiga sebanyak 65 juta, Rusia 61 juta, Amerika Serikat 58 juta, Jepang 49 juta, Brazil 24 juta, Bangladesh 23,3 juta, Jerman 22,3 juta, Turki 21,5 juta perokok. (Bahaya et al., 2019) Menurut Kemenkes RI, di Indonesia prevalensi 2017 kebiasaan merokok juga meningkat pada generasi muda bahwa prevalensi remaja usia 15 - 19 tahun yang merokok meningkat 2 kali lipat dari 12,7\% ditahun 2001 menjadi 23,1\% pada tahun 2016, prevalensi perokok anak usia 18 tahun meningkat dari 7,2\% menjadi 8,8\% pada tahun 2016. (Kesehatan, 2019) Di Indonesia 2018, prevalensi remaja perokok usia 10-18 tahun di Indonesia mengalami peningkatan yaitu pada tahun 2013 sebanyak 7,2\% , pada tahun 2016 sebanyak 8,8\%, dan pada tahun 2018 sebanyak 9,1\%. (Josten \& Nim, 2019).

Menurut Riset Kesehatan Dasar (Riskesdas) Tahun 2018 prevalensi merokok provinsi Sumatera Utara pada usia $\geq 10$ tahun yaitu sebanyak $28,8 \%$, prevalensi konsumsi tembakau pada usia $\geq 15$ tahun yaitu sebanyak $67,7 \%$ dimana $62,9 \%$ berjenis kelamin laki-laki dan $4,8 \%$ berjenis perempuan dan selanjutnya prevalensi populasi merokok pada usia 10-18 tahun yaitu sebanyak 9,1\% dengan target Rencana Pembangunan Jangka Menengah (RPJM) tahun 2019 5,4\% . (Riskesdas 2018 Berdasarkan hasil survey awal yang dilakukan oleh peneliti di SMP Free Metodist 1 Medan Jl. Beringin Raya No 152E, Helvetia, Kec. Medan Helvetia Tahun 2021 dengan melakukan wawancara pada remaja kelas IX terhadap pengetahuan mengenai sikap dan perilaku merokok ditemukan 6 orang mengetahui tentang pengetahuan sikap dan perilaku merokok serta 9 orang tidak mengetahui tentang pengetahuan sikap dan perilaku merokok.

\section{METODE}

Rancangan penelitian yang digunakan dalam penelitian ini adalah rancangan penelitian survei yang bersifat deskriptif, yang bertujuan untuk mendeskripsikan atau memaparkan Gambaran Pengetahuan Dan Sikap Remaja Tentang Perilaku Merokok Di SMP Free Metodist 1 Medan Jl. Beringin Raya No 152E, Helvetia, Kec. Medan Helvetia Tahun 2021.

Populasi pada penelitian ini adalah remaja putra kelas IX yang jumlah populasi 30 responden yang berada di SMP Free Metodist 1 Medan Jl. Beringin Raya No 152E, Helvetia, Kec. Medan Helvetia Tahun 2021. Sampel adalah sebagian dari elemen populasi . Sampel pada penelitian ini adalah remaja putra kelas IX SMP dengan metode Teknik Accidental sampling yaitu cara pengambilan sampel seketemunya, teknik ini didasarkan pada yang kebetulan ada atau yang bersedia untuk diteliti sebanyak 30 responden. Alat ukur yang digunakan untuk pengumpulan data pada penelitian ini adalah kuesioner. Kuesioner ini terdiri dari 20 pernyataan dengan pilihan jawaban benar atau salah. Apabila responden menjawab pernyataan benar maka nilainya 1 dan bila pernyataannya salah maka akan mendapat nilai 0 . Pengisian kuesioner ini 
dilakukan dengan cara memberikan tanda centang $(\sqrt{ })$ pada lembar kuesioner yang sudah disediakan. Dalam kuesioner ini terdapat 20 pernyataan.

Penelitian dilakukan pada 27 Mei 2021 di SMP Free Metodist 1 Medan Jl. Beringin Raya No 152E, Helvetia, Kec. Medan Helvetia Tahun 2021.Pengumpulan data penelitian setelah mendapat izin dari STIKes Santa Elisabeth Medan. Jenis pengumpulan data yang digunakan ada dua yaitu: data primer meliputi data yang diperoleh secara langsung dengan pemberian kuesioner pada siswi kelas IX. Pengumpulan Data diperoleh melalui wawancara, membagikan kuesioner, dan dokumentasi.

\section{HASIL}

Setelah dilakukan penelitian terhadap responden mengenai Gambaran Pengetahuan Dan Sikap Remaja Tentang Perilaku Merokok Di SMP Free Metodist 1 Medan Jl. Beringin Raya No 152E, Helvetia, Kec. Medan Helvetia Tahun 2021.

Tabel. 1. Gambaran Pengetahuan Remaja Tentang Perilaku Merokok Di SMP Free Metodist 1 Medan Jl. Beringin Raya No. 152E Helvetia, Kec. Medan Helvetia Tahun 2021

\begin{tabular}{ccc}
\hline Pengetahuan & Frekuensi & \% \\
\hline Baik & 7 & 23,3 \\
Cukup & 11 & 36,7 \\
Kurang & 12 & 40,0 \\
\hline Total & $\mathbf{3 0}$ & $\mathbf{1 0 0}$ \\
\hline
\end{tabular}

Berdasarkan data pada Tabel 1 diatas dapat diketahui bahwa Pengetahuan Remaja Tentang Perilaku Merokok di Sekolah SMP Free Metodist 1 Medan tahun 2021. Ditemukan bahwa paling banyak responden memiliki berpengetahuan kurang sebanyak 12 orang dengan presentase 40,0\%, dan ditemukan paling sedikit responden berpengetahuan baik sebanyak 7 orang dengan presentase $23,3 \%$.

Tabel 2 Distribusi Sikap Remaja tentang Perilaku Merokok Di SMP Free Metodist 1 Medan Jl. Beringin Raya No. 152E Helvetia, Kec. Medan Helvetia Tahun 2021.

\begin{tabular}{ccc}
\hline Sikap & Frekuensi & \% \\
\hline Positif & 30 & 100 \\
Negatif & 0 & 0 \\
\hline Total & $\mathbf{3 0}$ & $\mathbf{1 0 0}$ \\
\hline
\end{tabular}

Berdasarkan data pada Tabel 2 diatas dapat diketahui bahwa Sikap Remaja Tentang Perilaku Merokok di Sekolah SMP Free Metodist 1 Medan Tahun 2021. ditemukan bahwa seluruh reponden memiliki bersikap positif sebanyak 30 orang dengan presentase $100 \%$. 


\section{PEMBAHASAN}

\section{Gambaran Pengetahuan Remaja Tentang Perilaku Merokok Di SMP Free Metodist 1 Medan Jl. Beringin Raya No. 152E Helvetia, Kec. Medan Helvetia Tahun 2021}

Berdasarkan hasil penelitian mengenai pengetahuan remaja tentang perilaku merokok di SMP Free Metodist 1 Medan Jl. Beringin Raya No. 152E Helvetia, Kec. Medan Helvetia Tahun 2021. Didapatkan dari 30 responden menunjukkan bahwa paling banyak yang memiliki berpengetahuan Kurang 12 orang $40.0 \%$, berpengetahuan Cukup 11 orang $36.7 \%$ dan paling sedikit yang memiliki berpengetahuan baik terdapat 7 orang $23.3 \%$. Hal ini disebabkan karna kurangnya pengetahuan remaja mengenai pengetahuan tentang perilaku merokok.

Pengetahuan merupakan hasil "tahu" dan ini terjadi setelah orang mengadakan penginderaan terhadap suatu objek tertentu. Penginderaan terhadap objek terjadi melalui panca indra manusia yakni penglihatan, pendengaran, penciuman, rasa dan raba dengan sendiri. Pada waktu pengindraan sampai menghasilkan pengetahuan tersebut sangat dipengaruhi oleh intensitas perhatian persepsi terhadap objek. Sebagian besar pengetahuan manusia diperoleh melalui mata dan telinga. (Dewi, 2019)

Pengetahuan merupakan hasil mengingat sesuatu hal, termasuk mengingat kembali kejadian yang pernah dialami baik secara sengaja maupun tidak sengaja dan ini terjadi setelah orang melakukan kontak atau pengamatan terhadap suatu obyek tertentu.

Penelitian ini sejalan dengan hasil penelitian yang dilakukan oleh Sintia Mamonto dan Sri Rahayu Ningshi yang berjudul "Hubungan Pengetahuan Dengan Perilaku Merokok Pada Siswa SMP Negeri 9 Kotamobagu". Pada penelitian ini didapatkan hasil bahwa remaja yang berpengetahuan kurang dengan peresentase $57.8 \%$ atau sebanyak 23 orang dari 40 responden.

Menurut asumsi sintia dan sri, apabila responden memiliki pengetahuan yang baik tentang bahaya merokok di usia remaja maka dengan sendirinya responden akan takut terhadap konsekuensi yang didapat di kemudian hari. Pada masa remaja merupakan fase yang dimana remaja sangat mudah terpengaruh apabila diajak dalam melakukan hal-hal baru seperti perilaku merokok dan akibatnya akan menimbulkan efek ketergantungan dalam hal merokok.

Penelitian ini sejalan dengan hasil penelitian yang dilakukan oleh Nurul Azmi Nasution yang berjudul "Gambaran Pengetahuan Dan Sikap Remaja Tentang Merokok Di SMP NEGERI 41 MEDAN Tahun 2017". Pada penelitian ini didapatkan hasil bahwa remaja yang berpengetahuan cukup dengan presentase $51.3 \%$ atau sebanyak 39 orang dari 76 responden.

Menurut asumsi nurul, pengetahuan yang cukup dikarenakan responden hanya sekedar mengetahui apa itu bahaya rokok tetapi tidak terlalu memahami apa sebenarnya rokok tersebut, apa saja kandungannya, dan mengapa dapat berbahaya bagi kesehatan.

Penelitian ini sejalan dengan hasil penelitian yang dilakukan oleh Ali Muchtar yang berjudul "Gambaran Pengetahuan Dan Sikap Siswa SMP NEGERI 40 Palembang Terhadap Merokok Tahun 2017'. Pada penelitian ini didapatkan hasil bahwa remaja yang berpengetahuan kurang dengan presentase $33,3 \%$ atau sebanyak 90 orang dari 270 responden.

Menurut asumsi ali, tingkat pendidikan yang lebih rendah dan belum adanya materi pelajaran di sekolah khusus perilaku merokok serta kurangnya pemberian informasi ataupun pengetahuan mengenai rokok dan bahayanya di lingkungan keluarga.

Menurut asumsi peneliti, hasil penelitian yang berpengetahuan kurang data dibentuk berdasarkan tingkatan pengetahuan, tahu, memahami, aplikasi, analisis, sintesis. Hal ini sejalan dengan teori yang diungkapkan oleh Dewi (2019) bahwa pengetahuan atau kognitif merupakan dominan yang sangat penting untuk terbentuknya tindakan seseorang (ovent behavior). Dari pengalaman dan penelitian ternyata 
perilaku yang didasari oleh pengetahuan akan lebih tinggi dari pada perilaku yang tidak didasari oleh pengetahuan.

\section{Gambaran Sikap Remaja Tentang Perilaku Merokok Di SMP Free Metodist 1 Medan Jl. Beringin Raya No. 152E Helvetia, Kec. Medan Helvetia Tahun 2021.}

Berdasarkan hasil penelitian mengenai Sikap Remaja Tentang Perilaku Merokok di SMP Free Metodist 1 Medan Jl. Beringin Raya No. 152E Helvetia, Kec. Medan Helvetia Tahun 2021. Didapatkan dari 30 responden menunjukkan bahwa seluruh responden yang memiliki bersikap positif terdapat 30 orang $(100 \%)$.

Teori menyebutkan bahwa Sikap (attitude) merupakan konsep paling penting dalam psikologi sosial yang membahas unsur sikap sebagai individu maupun kelompok. Banyak kajian dilakukan untuk merumuskan pengertian sikap, proses terbentuknya sikap, maupun perubahan. Banyak pula penelitian telah dilakukan terhadap sikap kaitannya dengan efek dan perannya dalam pembentukan karakter dan sistem hubungan antar kelompok serta pilihan-pilihan yang ditentukan berdasarkan lingkungan dan pengaruhnya terhadap perubahan.

Menghargai (valuing), mengajak orang lain untuk mengerjakan atau Untuk dapat menjadi dasar pembentukan sikap, pengalaman pribadi haruslah meninggalkan kesan yang kuat. Karena itu, sikap akan lebih mudah terbentuk apabila pengalaman pribadi tersebut terjadi dalam situasi yang melibatkan faktor emosional.

Komponen afektif berhubungan dengan bagaimana perasaan yang timbul pada seseorang yang menyertai sikapnya, dapat positif serta dapat juga negatif terhadap objek sikap. Bila seseorang yang mempunyai sikap yang positif terhadap objek sikap, maka ini berarti adanya hubungan pula dengan nilainilai positif yang lain yang berhubungan dengan objek sikap tersebut, demikian juga dengan sikap yang negatif.

Penelitian ini sejalan dengan hasil penelitian yang dilakukan oleh Nurul Azmi Nasution yang berjudul "Gambaran Pengetahuan dan Sikap remaja Tentang Merokok di SMP Negeri 41 Medan Tahun 2017". Pada penelitian ini didapatkan hasil bahwa bersikap positif dengan presentase $92.1 \%$ atau sebanyak 70 orang dari 76 responden.

Menurut asumsi nurul, sikap yang positif terjadi karena keterkaitannya dengan pengetahuan yang dimiliki serta pengalaman dan paparan informasi yang didapatkan responden dalam lingkungannya, sehingga dievaluasikan dalam bentuk sikap yang positif. Sedangkan sikap yang negatif terjadi karena asumsi responden terhadap dirinya yang merasa sudah dewasa, sehingga ia merasa tidak setuju terhadap larangan merokok tersebut.

Penelitian ini sejalan dengan hasil penelitian yang dilakukan oleh Erike Septa Prautami dan Sri Rahayu yang berjudul "Hubungan Pengetahuan Dan Sikap Dengan Perilaku Merokok Pada Remaja Di SMA PGRI 2 Palembang Tahun 2017". Pada penelitian ini didapatkan hasil bahwa bersikap positif dengan presentase $74,2 \%$ atau sebanyak 89 orang dari 120 responden.

Menurut asumsi erike dan sri, perilaku yang didasari pengetahuan akan lebih langgeng dari pada perilaku yang tidak didasari oleh pengetahuan. Bila pengetahuan mereka sudah baik tentang merokok maka perilaku merokok akan berkurang. Persamaan hasil penelitian ini dengan penelitian terdahulu yang menunukkan bahwa ada hubungan antara pengetahuan dengan perilaku merokok disebabkan karena sampel yang digunakan adalah remaja dimana pengetahuan remaja masih kurang dan masih dipengaruhi oleh lingkungan atau teman sebaya.

Selain itu, tingginya kebiasaan merokok pada siswa SMA PGRI 2 Palembang disebabkan karena pengaruh dari pergaulan atau teman sebaya. Dimana merokok sudah menjadi tren dalam pergaulan di lingkungan remaja saat ini. Selain itu, hal ini juga dapat disebabkan karena kurangnya pengawasan dari keluarga maupun lingkungan masyarakat. 
Menurut asumsi peneliti, kesimpulan sikap data dibentuk berdasarkan komponen kognitif yaitu kepercayaan yang dimiliki, komponen afektif perasaan yang emosional dan juga kecenderungan berperilaku tertentu sesuai dengan sikap yang dimiliki oleh seseorang. Hal ini sejalan dengan teori yang diungkapkan oleh Eagly \& Chaiken (1993) mengemukakan bahwa sikap dapat diposisikan sebagai hasil evaluasi terhadap objek sikap, yang diekspresikan ke dalam proses-proses kognitif, afektif, dan komponen konatif.

\section{KESIMPULAN}

Dari hasil penelitian yang telah dilakukan terhadap Gambaran Pengetahuan dan Sikap Remaja Tentang Perilaku Merokok Di SMP Free Metodits 1 Medan Jl. Beringin Raya No 152E Helvetia, Kec. Medan Helvetia Tahun 2021.

Berdasarkan dari hasil penelitian yang telah dilakukan bahwa, gambaran pengetahuan remaja tentang perilaku merokok di SMP Free Metodist 1 Medan Jl. Beringin Raya No 152E Helvetia, Kec. Medan Helvetia Tahun 2021, berdasarkan pengetahuan terdapat paling banyak responden yang memiliki berpengetahuan kurang terdapat 12 orang (40.0\%), berpengetahuan Cukup 11 orang (36.7\%), dan paling sedikit berpengetahuan Baik 7 orang (23.3\%).

Berdasarkan dari hasil penelitian yang dilakukan bahwa, sikap remaja tentang perilaku merokok di SMP Free Metodist 1 Medan Jl. Beringin Raya No 152E Helvetia, Kec. Medan Helvetia Tahun 2021, didapatkan seluruh responden Yang bersikap positif terdapat 30 orang $(10.0 \%)$

\section{DAFTAR PUSTAKA}

Astuti, T. (2019). Faktor-Faktor yang Mempengaruhi Pengetahuan dan Sikap Remaja Tentang Dampak Rokok Bagi Kesehatan Reproduksi di Dusun 1 Desa Bakaran Batu Kecamatan Percut Sei Tuan Kabupaten Deli Serdang Tahun 2019. Excellent Midwifery, 02, 74-77.

Bahaya, T., Di, M., \& Negeri, S. M. A. (2019). Pengaruh Media Poster Terhadap Pengetahuan Tanjungbalai Tahun 2019 Program Studi S1 Kesehatan Masyarakat Fakultas Kesehatan Masyarakat Tentang Bahaya Merokok Di Sma Negeri 1 Tanjungbalai.

Dewi, A. W. dan. (2019). PENGETAHUAN, SIKAP, DAN PERILAKU MANUSIA (B. Jhon (ed.); III). Nuha Medika.

Handayani, D. (2019). Hubungan Pengetahuan Dan Sikap Dengan Perilaku Merokok Santriwan Di Pondok Pesantren Al-Jihad Surabaya. Medical Technology and Public Health Journal, $3(2), 120-126$.

Hutabarat, E. N. N., Rochadi, R. K., \& Aulia, D. (2019). Pengaruh Karakteristik Dan Persepsi Individu Tentang Peringatan Bahaya Merokok Pada Bungkus Rokok Terhadap Perubahan Sikap Perokok Aktif Di Lingkungan Xxvii Kelurahan Pekan Labuhan Kecamatan Medan Labuhan. Jurnal Muara Sains, Teknologi, Kedokteran Dan Ilmu Kesehatan, 3(1), 9.

Isa, L., Lestari, H., \& Afa, J. R. (2017). Hubungan Tipe Kepribadian, Peran Orang tua dan 
Saudara, Peran Teman Sebaya, dan Peran Iklan Rokok dengan Perilaku Merokok pada Siswa SMP Negeri 9 Kediri Tahun 2017. Jurnal Ilmiah Mahasiswa Kesehatan Masyarakat, 2(7), 1-10.

Josten, R., \& Nim, B. (2019). Gambaran Pengetahuan Siswa Tentang Bahaya Merokok Di Smp Swasta Pencawan Medan Tahun 2019. 2018.

K.f.ompusunggu, T. K. (2018). Gambaran Pengetahuan Dan Sikap Siswa Smp Deli Murni Delitua Terhadap Bahaya Merokok.

Kelian, M. T., Alimudin, L., \& Syafri, O. (2016). Persepsi Perokok Aktif dalam Menanggapi Label Peringatan Bahaya Merokok. Jurnal Fikratuna, 8(2), 54-65.

Kementerian Kesehatan Republik Indonesia. (2017). Infodatin Reproduksi Remaja-Ed.Pdf. In Situasi Kesehatan Reproduksi Remaja (pp. 2442-7659).

Kesehatan, J. (2019). Muhammadiyah Cipondoh. 8(1). https://doi.org/10.37048/ kesehatan.v8i1.53

Lingkungan, D. I., Club, M. X., \& Mcs, S. (2018). Gambaran Pengetahuan Remaja Tentang Bahaya Rokok Samarinda.

Negoro, S. H. (2017). Pembentukan Sikap Oleh Perokok Remaja Melalui Peringatan Bahaya Merokok Pada Kemasan Rokok. Interaksi: Jurnal Ilmu Komunikasi, 5(2), 112.

Pengetahuan, P., Tentang, S., Rokok, B., Dari, D., Kesehatan, S., Hapis, A. A., Husaini, A., Studi, P., Masyarakat, K., Tinggi, S., Kesehatan, I., \& Ibu, H. (2020). Jurnal Pengabdian KITA. 01(01).

Persica, S., Menurunkan, D., \& Plak, S. (2017). Vol. XI Jilid 2 No.74 Januari 2017 MENARA Ilmu. Jurnal Penelitian Dan Kajian Ilmiah, XI(74), 20-25.

Prautami, E. S., \& Rahayu, S. (2019). Hubungan Pengetahuan dan Sikap dengan Perilaku Merokok pada Remaja di SMA PGRI 2 Palembang Tahun 2017. Nursing Inside Community, 1(1), 27-32.

Prihatiningsih, D., Devhy, N. L. P., Purwanti, I. S., Bintari, N. W. D., \& Widana, A. G. O. (2020). Penyuluhan Bahaya Rokok Untuk Meningkatkan Kesadaran Remaja Mengenai Dampak Buruk Rokok Bagi Kesehatan Di Smp Tawwakal Denpasar. Jurnal Pengabdian Kesehatan, 3(1), 50-58.

Siswa, P., Tentang, R., Merokok, B., \& Rambah, N. (2017). Pengetahuan Siswa Remaja Tentang Bahaya Merokok di SMP Negeri 2 Rambah Hilir Kabupaten Rokan Hulu. 2(2), 178-183.

Sulastri, S., \& Rindu, R. (2019). Perbedaan Pengetahuan dan Sikap Remaja Sebelum dan Sesudah Promosi kesehatan Tentang Dampak Rokok. Jurnal Ilmu Kesehatan 


\section{Health Caring: Jurnal Illmiah Kesehatan}

Volume : 02| Nomor 01 | Bulan Juli Tahun 2022 |E-ISSN : 2809-9117|

DOI: doi.org/healthcaring.v2n1.2022

Masyarakat, 8(02), 61-72.

Susanto, A. (2020). Peningkatan Kesadaran Bahaya Asap Rokok Bagi Kesehatan Melalui Penyuluhan Pada Siswa Smp Negeri 1 Tegal. Dinamisia: Jurnal Pengabdian Kepada Masyarakat, 4(1), 68-73.

Wirawan, A. S. (2016). Jurnal Keperawatan dan Kesehatan MEDISINA AKPER YPIB Majalengka\#Volume II Nomor 3 Februari 2016 Hubungan Antara Pengetahuan Dan Sikap Tentang Bahaya Merokok Bagi Kesehatan Dengan Tindakan Merokok Pelajar Smk Negeri Talaga. Jurnal Keperawatan Dan Kesehatan MEDISINA AKPER YPIB Majalengka, II(3).

Yuda, A. prasetiya. (2018). Hubungan Pengetahuan Dan Sikap Tentang Bahaya Rokok Dengan Perilaku Merokok Pada Remaja Putra Di Smp Negeri 1 Dolopo Oleh. Stikes Bhakti Husada Mulia Madiun. 